\title{
PENGARUH KEPEMIMPINAN, KOMPETISI, GANJARAN DAN MOTIVASI KERJA TERHADAP EFEKTIVITAS ORGANISASI, BADAN PEMERIKSA KEUANGAN (BPK RI) JAKARTA
}

\author{
Nuraida Hidayati \\ Mahasiswa Pascasarjana Program Studi Pendidikan Kependudukan dan \\ Lingkungan Hidup
}

\begin{abstract}
This causal research is aimed at obtaining information related to the effect of leadership, competition, rewards and motivation to work on the effectiveness of organization.

In this research, 70 samples were selected randomly and the data has been analysed by path analysis after all variables put into the correlation matrix.

The finding of the research shows that effectiveness of organization is affected directly and indirectly by leadership, competition, rewards and motivation to work.

Based on those findings, it can be concluded that any changes or variations which occured at the effectiveness of organization are affected by leadership, competition, rewards and motivation to work.

Therefore, in increasing the effectiveness of organization, leadership, competition, rewards and motivation to work should be put into strategic planning of human resources in the Indonesian Audit Supreme Board Jakarta (BPK RI Jakarta); however other variables are necessary to be taken into account by the next research.
\end{abstract}

\section{PENDAHULUAN}

\section{A. Latar Belakang}

Untuk mencapai visi, misi, dan tujuantujuan organisasi, BPK telah mengembangkan sasaran-sasaran strategis dan rencana aksi di bidang kepemimpinan; perencanaan strategis; pemangku kepentingan; pengukuran, analisis, pengelolaan pengetahuan; sumber daya manusia; dan pengelolaan proses.

BPK berketetapan untuk melaksanakan suatu sistem manajemen yang terintegrasi dan praktek-praktek pemeriksaan yang dapat menyajikan hasil-hasil pemeriksaan dan pelayanan kepada para pemangku kepentingan. BPK menerapkan kriteria dan kerangka kerja berikut yang akan mengarahkan pengembangan BPK yang merupakan Rencana Strategis BPK RI tahun 2006-2010.

Diperlukan pengembangan BPK dengan meningkatkan efektivitas organisasi. Banyak faktor yang mempengaruhi baik eksternal maupun internal, namun pada penelitian ini penulis melihat efektivitas organisasi dari segi kepemimpinan, ganjaran, kompetisi dan motivasi kerja pada BPK RI Jakarta.

\section{B. Identifikasi Masalah}

Banyak faktor yang berpengaruh terhadap efektivitas organisasi baik dari individu sebagai penggerak organisasi maupun dari lingkungan eksternal. Individu ini bergantung pada kemampuan dan perannya. Faktor yang mempengaruhi efektivitas organisasi di antaranya kepemimpinan, ganjaran, kompetisi dan motivasi kerja. Kebijakan pemimpin dapat mempengaruhi ganjaran dan secara tidak langsung berpengaruh terhadap motivasi kerja yang pada akhirnya akan mempengaruhi efektivitas organisasi. Faktor lingkungan yang berpengaruh terhadap organisasi adalah lingkungan ekonomi, fisik dan teknologi. Adanya kompetisi yang berasal dari faktor lingkungan internal dan eksternal organisasi juga dapat memacu motivasi kerja sehingga mempengaruhi efektivitas organisasi.

\section{Perumusan Masalah}

1. Apakah motivasi kerja berpengaruh langsung terhadap efektivitas organisasi?

2. Apakah kompetisi berpengaruh langsung terhadap efektivitas organisasi?

3. Apakah ganjaran berpengaruh langsung terhadap efektivitas organisasi?

4. Apakah kepemimpinan berpengaruh tidak langsung terhadap efektivitas organisasi melalui ganjaran dan motivasi kerja?

\begin{tabular}{|c|c|c|c|}
\hline Volume XI & Nomor 01 & Maret 2010 & ISSN 1411-1829 \\
\hline
\end{tabular}


5. Apakah kepemimpinan berpengaruh tidak langsung terhadap efektivitas organisasi melalui kompetisi dan motivasi kerja?

6. Apakah ganjaran berpengaruh tidak langsung terhadap efektivitas organisasi melalui motivasi kerja?

7. Apakah kompetisi berpengaruh tidak langsung terhadap efektivitas organisasi melalui motivasi kerja?

8. Apakah kepemimpinan berpengaruh langsung terhadap ganjaran?

9. Apakah kepemimpinan berpengaruh langsung terhadap kompetisi?

10. Apakah kepemimpinan berpengaruh langsung terhadap motivasi kerja?

11. Apakah ganjaran berpengaruh langsung terhadap motivasi kerja?

12. Apakah kompetisi berpengaruh langsung terhadap motivasi kerja?

13. Apakah kepemimpinan berpengaruh tidak langsung terhadap motivasi kerja melalui ganjaran?

14. Apakah kepemimpinan berpengaruh tidak langsung terhadap motivasi kerja melalui kompetisi?

15. Apakah kepemimpinan berpengaruh tidak langsung terhadap efektivitas organisasi melalui kompetisi?

16. Apakah kepemimpinan berpengaruh tidak langsung terhadap efektivitas organisasi melalui ganjaran?

17. Apakah kepemimpinan berpengaruh tidak langsung terhadap efektivitas organisasi melalui motivasi kerja?

\section{DESKRIPSI TEORETIK}

\section{A. Teori Ahli}

\section{Efektivitas Organisasi}

Ada beberapa definisi efektivitas organisasi yang dikemukakan oleh para ahli. Tingkat efektivitas penting untuk diketahui setiap organisasi karena dapat digunakan untuk mengukur kesuksesan organisasi tersebut.

Pengertian efektivitas berdasarkan pendekatan tujuan menurut Gibson (2006:20) adalah pencapaian tujuan dari usaha bersama. Tingkat pencapaian mengindikasikan tingkat efektivitas atau keefektifan.
Banyak faktor yang dapat mempengaruhi suatu efektivitas organisasi. Namun pada penelitian yang dilakukan, variabel-variabel yang mempengaruhi efektivitas organisasi dibatasi pada variabel kepemimpinan, kompetisi, ganjaran, dan motivasi kerja. Hal itu karena variabel-variabel tersebut dianggap memiliki pengaruh terhadap efektivitas organisasi BPK RI Jakarta sesuai teori Handy dalam Mullins.

Pada penelitian ini, efektivitas organisasi adalah penilaian terhadap keberhasilan kerja seseorang sesuai dengan target yang telah ditentukan dalam kurun waktu tertentu. 


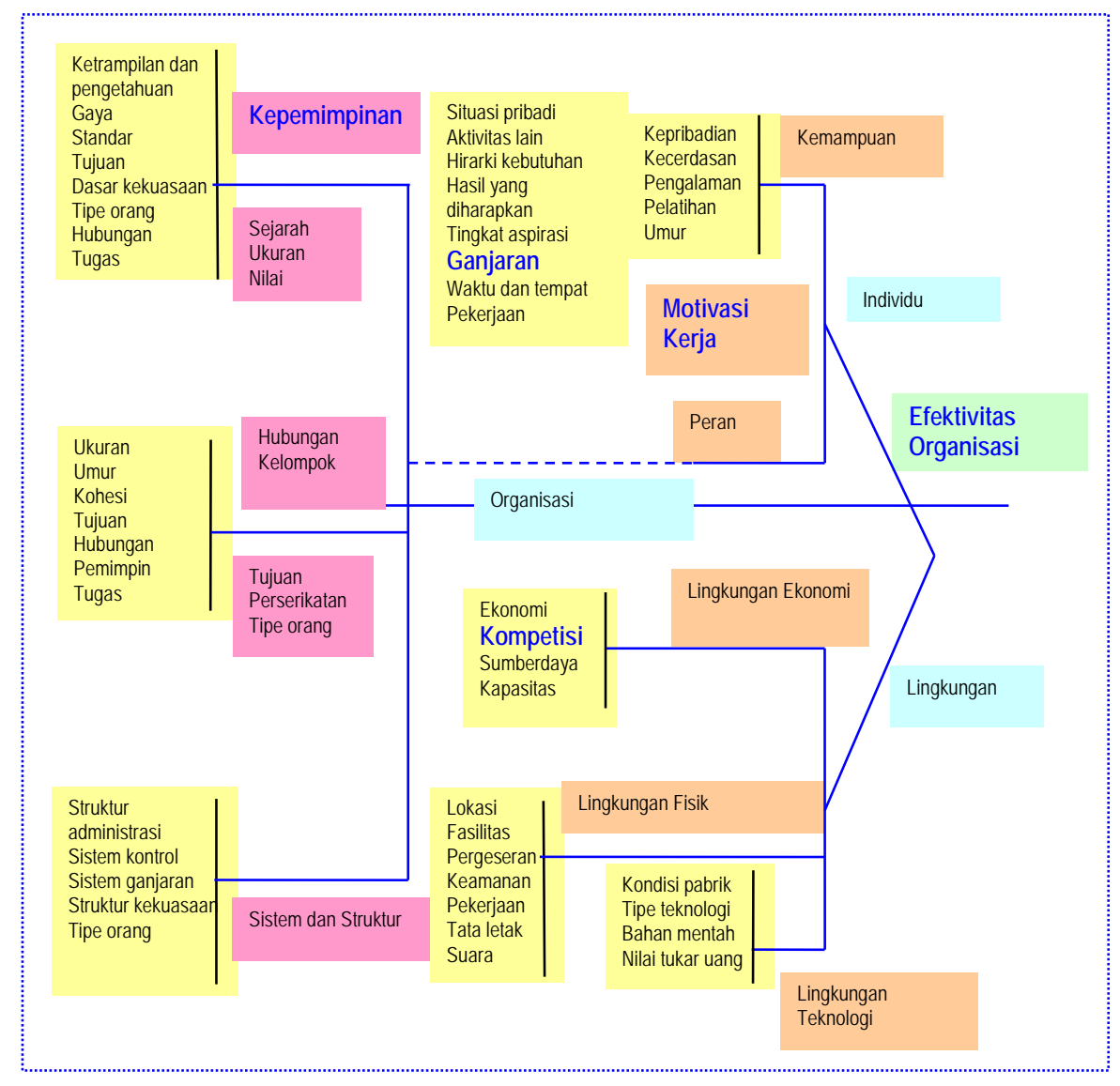

Gambar 2.1. Faktor-faktor yang mempengaruhi efektivitas organisasi menurut Handy dalam Mullins (2005:959)

\section{Motivasi Kerja}

Motivasi kerja berasal dari motivasi untuk bekerja. Motivasi kerja merupakan dorongan untuk bekerja yang berasal dari dalam dan luar diri seseorang.

Daft (2005:294) memberikan pengertian tentang motivasi sebagai dorongan dari dalam dan luar diri seseorang yang menimbulkan antusiasme dan kegigihan untuk melakukan suatu tindakan.

Berdasarkan teori di atas, motivasi kerja dapat didefinisikan sebagai sesuatu yang menggerakkan baik dari dalam diri maupun lingkungan seseorang sehingga menimbulkan semangat untuk bekerja lebih giat dalam mencapai tujuan.

Menurut Atkinson dan Birch (1978:11) bahwa tujuan akhir dari penelitian motivasi adalah untuk meningkatkan pemahaman mengenai tingkah laku manusia.
Berdasarkan teori di atas, diketahui motivasi kerja sangat mempengaruhi perilaku individu. Dengan motivasi kerja auditor yang tinggi diharapkan efektivitas organisasi BPK RI Jakarta akan meningkat. Dengan demikian, perlu pemahaman yang baik mengenai hal-hal yang mendorong dan menurunkan motivasi kerja auditor.

Pada penelitian ini, motivasi kerja adalah dorongan seseorang untuk bekerja lebih giat yang ditimbulkan oleh faktor dalam dan luar.

\section{Ganjaran}

Ganjaran dibutuhkan oleh setiap karyawan karena merupakan suatu pengakuan dan penghargaan dari organisasi tempatnya bekerja. Ganjaran bermacam-macam bentuknya, baik berupa finansial maupun nonfinansial. Ada beberapa teori yang menjelaskan mengenai ganjaran. 
Menurut Luthans (1995:203) ganjaran adalah sesuatu yang diinginkan orang. Ganjaran adalah sesuatu yang diberikan kepada orang dan dianggap hal itu diinginkan oleh orang tersebut.

Berdasarkan pengertian di atas, ganjaran adalah sesuatu yang sangat diharapkan dapat diperoleh seseorang setelah berusaha bekerja dengan baik. Ganjaran merupakan bagian dari sistem kompensasi. Dalam penelitian ini, ganjaran dibatasi pada aspek nonfinansial seperti kesempatan promosi jabatan, pelatihan dan pendidikan, tanda jasa, dan sebagainya.

Prinsip sistem ganjaran yang efektif menurut Wilson (1995:30) adalah:

1. Sistem ganjaran perlu untuk memberikan dampak positif bagi tindakan seseorang;

2. Sistem ganjaran perlu untuk memfokuskan usaha pada pelayanan pelanggan; dan

3. Sistem ganjaran perlu untuk meningkatkan kolaborasi di tempat kerja.

Ganjaran berpengaruh secara positif terhadap motivasi kerja auditor karena seseorang dapat lebih fokus pada pekerjaannya dan dapat bekerjasama lebih baik dalam menyelesaikan tugas. Penelitian ini melihat pengaruh ganjaran terhadap motivasi kerja dan pada akhirnya berpengaruh terhadap efektivitas organisasi secara keseluruhan di BPK RI Jakarta.

Pada penelitian ini, ganjaran adalah penilaian terhadap sistem penghargaan yang diberlakukan di suatu organisasi.

\section{Kompetisi}

Kompetisi dalam penelitian yang dilakukan adalah bersaing secara sehat dalam bekerja untuk peningkatan efektivitas organisasi.

Definisi kompetisi menurut Aguayo (1990:226-227) ada beberapa hal, yaitu:

1. Bersaing melawan (seperti dalam pertandingan);

2. Adanya beberapa alternatif (ada pembanding);

3. Sama baiknya (seperti);

4. Lebih baik dari lainnya;

5. Bersaing dengan (untuk perbaikan).

Dalam lingkungan yang terus berubah, akan terjadi kondisi yang kompetitif baik antara sesama karyawan maupun dengan lembaga sejenis. Untuk meraih kepercayaan masyarakat dan pemangku kepentingan, diperlukan keunggulan bersaing dari organisasi tersebut.

Porter (1994:206) menerangkan bahwa hadirnya pesaing yang "baik" dapat membawa berbagai manfaat strategis, salah satunya adalah meningkatkan keunggulan bersaing.

Sesuai teori-teori yang ada, pada penelitian ini kompetisi adalah penilaian terhadap adanya daya saing dalam menghadapi tantangan yang diindikasikan dengan adanya standar yang jelas. Budaya kompetisi di Indonesia tidak hanya persaingan saja tetapi juga diwarnai dengan adanya kerjasama atau gotong royong seperti mengadakan pelatihan bersama untuk meningkatkan kompetensi, menciptakan inovasi, dan menggunakan teknologi tinggi. Penelitian yang dilakukan adalah melihat pengaruh kompetisi terhadap motivasi kerja yang pada akhirnya secara keseluruhan mempengaruhi efektivitas organisasi di BPK RI Jakarta.

\section{Kepemimpinan}

Kepemimpinan itu kompleks sehingga tidak ada definisi yang universal mengenai kepemimpinan karena kepemimpinan itu dapat dipelajari dengan berbagai cara sehingga definisinya berlainan.

Kepemimpinan menurut BPK RI (2006:10) adalah bagaimana Badan mengarahkan Pelaksana BPK untuk mencapai visi, misi dan tujuan strategis BPK termasuk di dalamnya menyelenggarakan tata kelola Pelaksana BPK dan akuntabilitas para pemangku kepentingan.

Menurut Robbins (1990:347) kepemimpinan adalah kemampuan untuk mempengaruhi suatu kelompok melalui pencapaian tujuan.

Kepemimpinan berdasarkan teori-teori di atas adalah proses mempengaruhi bawahan yang dilakukan pemimpin untuk mencapai tujuan bersama. Pemimpin yang efektif memiliki kompetensi kepemimpinan dan akan mampu mewujudkan: kesuksesan pada organisasi yang dipimpinnya.

Buckingham (2005:197) mengatakan bahwa pemimpin yang efektif tidak melupakan sisi manusiawi dari orang lain. Jika semua itu dipenuhi maka mereka akan bekerja sepenuh hati untuk membuat tujuan bersama menjadi nyata. 
Praktek kepemimpinan yang memperhatikan sisi manusiawi sangat diperlukan oleh bawahan untuk memotivasi kerja agar lebih baik. Pada penelitian ini, kepemimpinan adalah perilaku pemimpin untuk mempengaruhi pengikutnya sesuai fungsinya sebagai perencana, pemrakarsa, pengendali, pendukung, sumber informasi dan penilai dalam mencapai tujuan organisasi.

\section{Hubungan-hubungan antara Efektivitas Organisasi, Ganjaran, Motivasi Kerja, Kompetisi dan Kepemimpinan}

1. Hubungan antara Kepemimpinan dan Motivasi Kerja

Motivasi kerja berkaitan erat dengan kepemimpinan dalam suatu organisasi. Pemimpin yang baik mampu meningkatkan motivasi kerja karyawan. Beberapa teori menjelaskan hubungan antara kepemimpinan dan motivasi kerja.

Menurut Yukl (1989:135), kepemimpinan didefinisikan secara luas meliputi proses yang mempengaruhi penentuan tujuan organisasi atau kelompok, memotivasi perilaku kerja untuk mencapai tujuan dan mempengaruhi keutuhan kelompok dan budaya.

Salah satu tugas pemimpin adalah memotivasi bawahan untuk bekerja lebih baik. Perilaku kepemimpinan dapat merupakan bakat alam sejak lahir ataupun dipelajari dari lingkungan. Dalam penelitian ini, peran pemimpin sebagai motivator sangat diperlukan dalam meningkatkan efektivitas organisasi BPK RI Jakarta.

\section{Hubungan antara Ganjaran dan Motivasi Kerja}

Ganjaran dan motivasi kerja sangat erat hubungannya. Ganjaran merupakan penggerak karyawan untuk bekerja lebih giat. Ganjaran adalah bagian dari kompensasi yang diberikan organisasi kepada karyawan.

Menurut Nelson (2007:13), hasil survei Council of Communication Management menegaskan apa yang sudah diketahui oleh hampir setiap karyawan bahwa pengakuan atas hasil kerja yang baik merupakan motivator utama kinerja karyawan.

Gouillart dan Keelly (1995:242) mengatakan sistem ganjaran memberikan rasa kepuasan. Jika sistem ganjaran individu mendorong sikap seseorang, maka sistem ganjaran perusahaan mendorong orang dalam kerja organisasi. Sistem ganjaran adalah penghubung di mana orang memutuskan untuk membuat tujuan perusahaan sebagai tujuan pribadi mereka.

Ganjaran memberikan kepuasan bagi auditor yang memperolehnya, karena hal itu merupakan pengakuan akan loyalitas dan jasanya. Pada penelitian ini, ganjaran berpengaruh pada motivasi kerja auditor di BPK RI Jakarta.

\section{Hubungan antara Ganjaran dan Efektivitas Organisasi}

Ganjaran berkaitan erat dengan efektivitas organisasi. Salah seorang ahli yang mengemukakan hal tersebut adalah Armstrong. Berdasarkan teori Armstrong (1996:4), diketahui sistem ganjaran akan berpengaruh terhadap peningkatan kinerja individu atau kelompok, dan pada akhirnya akan mempengaruhi peningkatan efektivitas organisasi. Dalam penelitian ini, ganjaran berpengaruh terhadap efektivitas organisasi BPK RI Jakarta baik secara langsung maupun tidak langsung melalui motivasi kerja.

\section{Hubungan antara Kepemimpinan dan Kompetisi}

Salah satu fungsi pemimpin adalah sebagai pendorong terciptanya kondisi yang kompetitif di lingkungan kerja. Untuk itu pemimpin akan berupaya mendorong adanya kompetisi yang sehat di antara karyawan maupun dengan lembaga sejenis.

Menurut Porter (2002:195) erat hubungannya antara kompetisi dan pemimpin. Kenyataan persaingan masa kini membutuhkan kepemimpinan. Pemimpin percaya pada perubahan, mereka menggerakkan organisasi untuk berinovasi secara terus-menerus, mereka menyadari pentingnya negara asalnya untuk kesuksesan kompetisi dan bekerja untuk meningkatkannya.

Kepemimpinan yang efektif berpengaruh terhadap adanya kompetisi yang sehat. Dalam penelitian yang dilakukan, kepemimpinan diketahui mempengaruhi kondisi yang kompetitif di BPK RI Jakarta. 


\section{Hubungan antara Kompetisi dan Efektivitas Organisasi}

Kompetisi berkaitan dengan efektivitas organisasi. Kompetisi yang sehat akan mendorong keberhasilan organisasi seperti yang dikatakan oleh teori di bawah ini.

Bainbridge (1999:1) menyebutkan bahwa suatu penelitian yang dilakukan oleh Litbang AL AS menyimpulkan bahwa di sekolah teknik AL ternyata kompetisi (perbandingan kinerja dengan siswa lain) berkorelasi dengan keberhasilan.

Perubahan keorganisasian (organizational change) menurut Winardi (2005:2-3) merupakan tindakan beralihnya suatu organisasi dari kondisi yang berlaku kini, menuju ke kondisi masa yang akan datang yang diinginkan guna meningkatkan efektivitasnya. Di antara faktor yang membantu perubahan organisasi adalah kekuatan-kekuatan kompetitif.

Kompetisi yang sehat sangat diperlukan untuk pembenahan organisasi secara berkelanjutan. Dalam penelitian ini, kompetisi berpengaruh secara langsung dan tidak langsung melalui motivasi kerja terhadap efektivitas organisasi.

\section{Hubungan antara Kepemimpinan dan Ganjaran}

Kepemimpinan erat hubungannya dengan ganjaran. Kepemimpinan yang baik akan memperhatikan terhadap sistem ganjaran yang berlaku di organisasi. Pemimpin akan mengusahakan sistem ganjaran yang memadai sehingga memuaskan para karyawan.

Daft (2005:98) menjelaskan tanggungjawab pemimpin adalah untuk menjelaskan jalur ganjaran untuk pengikut atau untuk meningkatkan jumlah ganjaran guna meningkatkan kepuasan dan kinerja.

Salah satu tugas pemimpin adalah membuat kebijakan mengenai sistem ganjaran. Dalam penelitian ini, melihat pengaruh langsung kepemimpinan terhadap ganjaran di BPK RI Jakarta.

\section{Hubungan antara Kompetisi dan Motivasi Kerja \\ Kompetisi merupakan salah satu faktor yang mendorong motivasi kerja karyawan.}

Dengan adanya kompetisi karyawan akan terus meningkatkan profesionalismenya.

Bainbridge (1999:1) menjelaskan bahwa dalam dunia militer digunakan kompetisi untuk memotivasi anggota militer dan untuk membuat keputusan penting. Dua anggota mungkin berkompetisi untuk suatu misi atau tugas. Tingkat pelaksanaan yang lebih tinggi dapat dicapai karena kelompok lebih penting daripada diri. Misalnya kelompok yang menang dalam suatu kontes akan diberi kebebasan oleh komandan, sedangkan yang kalah harus tetap di pos.

Kompetisi yang sehat akan memotivasi auditor untuk menjadi yang terbaik dalam bidangnya masing-masing. Dalam penelitian ini diketahui bahwa kompetisi memiliki pengaruh terhadap motivasi kerja auditor di BPK RI Jakarta.

\section{Hubungan antara Motivasi Kerja dan Efektivitas Organisasi}

Motivasi kerja karyawan secara keseluruhan akan mempengaruhi efektivitas organisasi. Dengan adanya motivasi kerja, berarti karyawan memiliki dorongan yang kuat untuk bekerja lebih baik.

Robbins (1990:50) menyatakan terdapat 30 kriteria efektivitas organisasi, salah satunya adalah motivasi.

Dalam penelitian ini, terlihat pengaruh motivasi kerja auditor terhadap efektivitas organisasi di BPK RI Jakarta.

\section{B. Kerangka Berpikir}

1. Pengaruh langsung motivasi kerja terhadap efektivitas organisasi

Motivasi kerja yang tinggi mampu mendorong auditor untuk bekerja lebih baik sehingga dapat tercapai efektivitas organisasi. Motivasi kerja berasal dari dalam dan luar diri auditor. Dengan adanya motivasi kerja, auditor akan berusaha keras dan dengan senang hati melakukan tugasnya untuk mencapai tujuan organisasi.

\section{Pengaruh langsung kompetisi terhadap efektivitas organisasi}

Adanya kompetisi akan mendorong terciptanya efektivitas organisasi. Oleh karena adanya keinginan untuk menjadi organisasi yang

\begin{tabular}{|l|c|c|c|}
\hline Volume XI & Nomor 01 & Maret 2010 & ISSN 1411-1829 \\
\hline
\end{tabular}


terbaik di antara organisasi yang sejenis di Indonesia maupun di dunia. Selain itu, kompetisi yang sehat antarauditor di dalam organisasi mendorong peningkatan kemampuan auditor di bidang masing-masing.

\section{Pengaruh langsung ganjaran terhadap efektivitas organisasi}

Ganjaran diberikan kepada auditor yang telah berjasa dan loyal terhadap organisasi. Ganjaran yang memadai akan memotivasi auditor untuk meningkatkan efektivitas kerja auditor. Efektivitas kerja auditor yang tinggi akan meningkatkan efektivitas organisasi.

\section{Pengaruh tidak langsung kepemimpinan terhadap efektivitas organisasi melalui ganjaran dan motivasi kerja \\ Peran kepemimpinan untuk membuat} kebijakan ganjaran dan motivasi kerja auditor mampu meningkatkan efektivitas organisasi. Pemimpin yang efektif mampu membuat kebijakan sistem ganjaran yang memadai dan mampu memuaskan auditor. Dengan demikian motivasi kerja auditor akan meningkat pula. Pada akhirnya, efektivitas organisasi dapat ditingkatkan.

5. Pengaruh tidak langsung kepemimpinan terhadap efektivitas organisasi melalui kompetisi dan motivasi kerja

Kepemimpinan berperan dalam meningkatkan efektivitas organisasi secara tidak langsung melalui kebijakan yang mampu mendorong adanya kompetisi yang sehat dalam lingkungan kerja. Sehingga auditor dapat termotivasi untuk meningkatkan efektivitas kerjanya yang pada akhirnya meningkatkan efektivitas organisasi.

6. Pengaruh tidak langsung ganjaran terhadap efektivitas organisasi melalui motivasi kerja

Secara tidak langsung, ganjaran juga berperan dalam peningkatan efektivitas organisasi. Dengan adanya ganjaran yang diharapkan auditor akan mampu meningkatkan motivasi kerjanya sehingga auditor akan bekerja lebih giat dalam mencapai tujuan organisasi.
Dengan demikian efektivitas organisasi dapat meningkat.

\section{Pengaruh tidak langsung kompetisi terhadap efektivitas organisasi melalui motivasi kerja \\ Dengan adanya iklim kompetisi dalam} suatu organisasi maka para auditor akan bersaing. Kompetisi yang sehat mendorong auditor meningkatkan kinerjanya antara lain melalui kreativitas dan inovasi. Kinerja auditor yang tinggi akan mendukung peningkatan efektivitas organisasi.

\section{Pengaruh langsung kepemimpinan terhadap ganjaran}

Peran kepemimpinan dalam menentukan kebijakan pemberian ganjaran terhadap auditor sangat besar. Kepemimpinan yang baik berupaya memenuhi kebutuhan dan keinginan auditor dengan menciptakan sistem ganjaran yang proporsional bagi setiap auditor.

\section{Pengaruh langsung kepemimpinan terhadap kompetisi}

Kepemimpinan cukup berperan mendorong adanya kondisi yang kompetitif dalam lingkungan kerja organisasi sehingga terjadi persaingan sehat antarauditornya dalam melaksanakan tugas agar tercapai tujuan organisasi. Serta adanya kompetisi dengan lembaga sejenis akan meningkatkan kinerja BPK.

\section{Pengaruh langsung kepemimpinan terhadap motivasi kerja \\ Kepemimpinan memegang peran penting} dalam memotivasi untuk bekerja bawahan. Motivasi sebagian berasal dari dalam diri seseorang dan sebagian lainnya berasal dari lingkungan hidupnya terutama dari kepemimpinan yang ditemui di lingkungan tersebut. Sehingga peran pemimpin di BPK diyakini memiliki pengaruh dalam memotivasi auditor untuk bekerja.

\section{Pengaruh langsung ganjaran terhadap motivasi kerja \\ Ganjaran adalah salah satu pendorong} motivasi kerja seseorang. Ganjaran yang sesuai harapan auditor dapat menjadi motivator auditor

\begin{tabular}{|c|c|c|c|}
\hline Volume XI & Nomor 01 & Maret 2010 & ISSN 1411-1829 \\
\hline
\end{tabular}


untuk bekerja lebih baik. Perbaikan kebijakan ganjaran akan meningkatkan motivasi kerja auditor.

\section{Pengaruh langsung kompetisi terhadap motivasi kerja}

Adanya kompetisi yang sehat merupakan salah satu motivator kerja auditor. Kompetisi ini baik yang berada dalam lingkungan kerja dalam organisasi itu sendiri (internal) misalnya kompetisi antarauditor maupun dengan lingkungan luar organisasi (eksternal) misalnya dengan organisasi sejenis.

\section{Pengaruh tidak langsung kepemimpinan} terhadap motivasi kerja melalui ganjaran

Kepemimpinan secara tidak langsung berperan dalam peningkatan motivasi kerja auditor dengan pembuatan kebijakan ganjaran seperti yang diharapkan auditor.

14. Pengaruh tidak langsung kepemimpinan terhadap motivasi kerja melalui kompetisi

Kompetisi yang terjadi cukup besar dipengaruhi oleh peran kepemimpinan. Pemimpin mampu menciptakan kondisi lingkungan kerja yang kompetitif sehingga akan memotivasi auditor untuk bekerja lebih baik.

15. Pengaruh tidak langsung kepemimpinan terhadap efektivitas organisasi melalui kompetisi

Kepemimpinan merupakan salah satu faktor yang mempengaruhi efektivitas organisasi dengan berbagai strategi. Salah satu caranya adalah dengan mendorong terciptanya suasana kompetisi yang sehat. Kompetisi yang sehat akan mampu memberikan pengaruh yang positif kepada kemajuan organisasi.

\section{Pengaruh tidak langsung kepemimpinan terhadap efektivitas organisasi melalui ganjaran \\ Pemimpin sangat berperan dalam} meningkatkan efektivitas organisasi. Pemimpin berupaya mendorong bawahannya untuk tercapainya tujuan organisasi dengan memberikan ganjaran terhadap bawahan yang telah berjasa dan loyal terhadap organisasi.
17. Pengaruh tidak langsung kepemimpinan terhadap efektivitas organisasi melalui motivasi kerja

Pemimpin yang efektif merupakan juga seorang motivator terhadap bawahannya. Pemimpin yang baik akan selalu memberikan dorongan dan dukungan kepada auditor agar dapat melaksanakan tugas dengan sebaik-baiknya untuk mencapai tujuan organisasi. Dengan demikian, kepemimpinan tersebut mampu meningkatkan efektivitas organisasi.

\section{Hipotesis Penelitian}

1. Kepemimpinan berpengaruh langsung terhadap ganjaran;

2. Kepemimpinan berpengaruh langsung terhadap kompetisi;

3. Kepemimpinan berpengaruh langsung terhadap motivasi kerja;

4. Kepemimpinan berpengaruh tidak langsung terhadap motivasi kerja melalui ganjaran;

5. Kepemimpinan berpengaruh tidak langsung terhadap motivasi kerja melalui kompetisi;

6. Kepemimpinan berpengaruh tidak langsung terhadap efektivitas organisasi melalui ganjaran dan motivasi kerja;

7. Kepemimpinan berpengaruh tidak langsung terhadap efektivitas organisasi melalui kompetisi dan motivasi kerja;

8. Ganjaran berpengaruh langsung terhadap motivasi kerja;

9. Ganjaran berpengaruh langsung terhadap efektivitas organisasi;

10. Ganjaran berpengaruh tidak langsung terhadap efektivitas organisasi melalui motivasi kerja;

11. Kompetisi berpengaruh langsung terhadap motivasi kerja;

12. Kompetisi berpengaruh langsung terhadap efektivitas organisasi;

13. Kompetisi berpengaruh tidak langsung terhadap efektivitas organisasi melalui motivasi kerja;

14. Motivasi kerja berpengaruh langsung terhadap efektivitas organisasi;

15. Kepemimpinan berpengaruh tidak langsung terhadap efektivitas organisasi melalui kompetisi;

\begin{tabular}{|l|l|l|l|}
\hline Volume XI & Nomor 01 & Maret 2010 & ISSN 1411-1829 \\
\hline
\end{tabular}


16. Kepemimpinan berpengaruh tidak langsung terhadap efektivitas organisasi melalui ganjaran;

17. Kepemimpinan berpengaruh tidak langsung terhadap efektivitas organisasi melalui motivasi kerja.

Untuk hubungan di atas dapat dilihat pada gambar model teori pada Gambar 1 berikut:

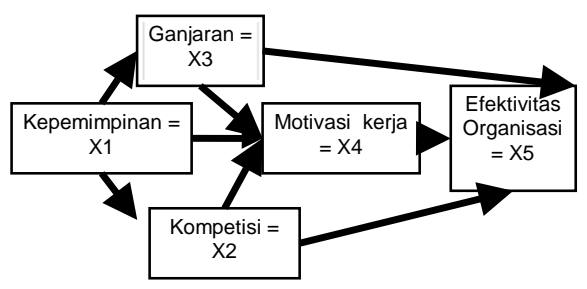

Sumber: Mullins, 2005.

Gambar 1. Model Hipotesis

\section{PENELITIAN}

Penelitian ini bertujuan untuk mencari pengaruh faktor-faktor kepemimpinan, kompetisi, ganjaran dan motivasi kerja terhadap efektivitas organisasi, dan juga untuk mengetahui besar (persentase) efektivitas BPK RI.

Tempat penelitian adalah lingkungan Badan Pemeriksa Keuangan (BPK RI) Jakarta. Sedangkan waktu penelitian dilakukan sejak November 2008 sampai sampai April 2009.
Metode yang digunakan dalam penelitian ini adalah metode survei dan pengumpulan data dilakukan dengan menyebarkan kuesioner kepada pegawai BPK RI Jakarta. Teknik analisis yang dilakukan adalah teknik analisis jalur (path analysis) dengan menggunakan software Lisrel. Teknik ini dilakukan untuk menganalisis pengaruh yang terdapat di antara variabelvariabel yang diduga berpengaruh langsung maupun tidak langsung terhadap efektivitas organisasi.

Populasi target adalah seluruh auditor BPK RI Jakarta. Adapun populasi terjangkau yang menjadi target penelitian adalah auditor di Auditorat Utama Keuangan Negara (AKN) I sampai VII (unit operasional) pada BPK RI Pusat Jakarta dengan persyaratan: (1) Pendidikan minimal Sarjana (S1);(2) Golongan III dan IV;(3) Lama kerja di atas 10 tahun.

Berdasarkan data statistik BPK (2006:30), diketahui populasi pegawai BPK RI Jakarta golongan III sampai dengan IV tahun 2005 berjumlah 1.505 orang.

Teknik pengambilan sampel dilakukan dengan sampel acak sederhana (simple random sampling), karena populasi target homogen yaitu auditor. Ukuran sampel menurut Roscoe dalam Sugiyono (2007:74) yang layak dalam penelitian adalah antara 30 sampai dengan 500. Jumlah sampel pada penelitian ini sebanyak 70 responden.

\section{HASIL PENELITIAN}

\section{A. Statistik Deskriptif}

\begin{tabular}{|l|r|r|r|r|r|}
\hline & Kepemimpinan & Kompetisi & Ganjaran & $\begin{array}{c}\text { Motivasi } \\
\text { Kerja }\end{array}$ & $\begin{array}{c}\text { Efektivitas } \\
\text { organisasi }\end{array}$ \\
\hline Responden & 70 & 70 & 70 & 70 & 70 \\
\hline Butir Pernyataan & 20 & 22 & 21 & 24 & 21 \\
\hline Rerata & 47,114 & 62,223 & 56,171 & 62,386 & 59,386 \\
\hline Median & 45,500 & 63,000 & 58,000 & 63,000 & 60,000 \\
\hline Modus & 41,000 & 66,000 & 60,000 & 63,000 & 60,000 \\
\hline Simpangan Baku & 7,013 & 3,707 & 5,343 & 6,032 & 3,013 \\
\hline Varian & 49,175 & 13,744 & 28,550 & 36,385 & 9,081 \\
\hline Rentang & 28,000 & 14,000 & 21,000 & 22,000 & 13,000 \\
\hline Minimum & 32,000 & 52,000 & 42,000 & 50,000 & 50,000 \\
\hline Maksimum & 60,000 & 66,000 & 63,000 & 72,000 & 63,000 \\
\hline Jumlah & $3.298,000$ & $4.356,000$ & $3.932,000$ & $4.367,000$ & $4.157,000$ \\
\hline
\end{tabular}

\begin{tabular}{|l|l|l|l|}
\hline Volume XI & Nomor 01 & Maret 2010 & ISSN 1411-1829 \\
\hline
\end{tabular}


Sumber: analisis penulis, 2009

B. Pengujian Persyaratan Analisis

1. Uji Normalitas

Tabel 2. Hasil Uji Normalitas Kolmogorov-Smirnov

\begin{tabular}{|l|c|c|l|}
\hline \multicolumn{1}{|c|}{ Variabel } & $\mathbf{a}_{\text {absolut }}$ & $\mathbf{a}_{\text {tabel } \boldsymbol{\alpha}=\mathbf{0 , 0 5}}$ & \multicolumn{1}{|c|}{ Kesimpulan } \\
\hline Efektivitas Organisasi (X5) & 0,138 & 0,163 & Normal \\
\hline Motivasi Kerja (X4) & 0,103 & 0,163 & Normal \\
\hline Ganjaran (X3) & 0,148 & 0,163 & Normal \\
\hline Kompetisi (X2) & 0,155 & 0,163 & Normal \\
\hline Kepemimpinan (X1) & 0,156 & 0,163 & Normal \\
\hline
\end{tabular}

Sumber: analisis penulis, 2009

\section{Uji Homogenitas Varians}

Tabel 3. Hasil Uji Homogenitas Varians

\begin{tabular}{|c|l|c|c|c|c|}
\hline No & \multicolumn{1}{|c|}{ Kelompok } & $\mathbf{X}_{\text {hitung }}$ & $\mathbf{X}_{\text {tabel } \boldsymbol{a}=\mathbf{0 , 0 5}}$ & $\begin{array}{c}\text { dk (derajat } \\
\text { kebebasan) }\end{array}$ & Keterangan \\
\hline 1 & X2 atas X1 & 24,20 & 64,00 & 47 & Homogen \\
\hline 2 & X3 atas X1 & 24,49 & 64,00 & 47 & Homogen \\
\hline 3 & X4 atas X1 & 24,35 & 64,00 & 47 & Homogen \\
\hline 4 & X4 atas X2 & 6,40 & 75,62 & 57 & Homogen \\
\hline 5 & X4 atas X3 & 18,17 & 68,67 & 51 & Homogen \\
\hline 6 & X5 atas X2 & 15,94 & 75,62 & 57 & Homogen \\
\hline 7 & X5 atas X3 & 31,96 & 68,67 & 51 & Homogen \\
\hline 8 & X5 atas X4 & 8,16 & 66,34 & 49 & Homogen \\
\hline
\end{tabular}

Sumber: analisis penulis, 2009

\section{Uji Signifikansi Koefisien Regresi dan Uji Linearitas}

Tabel 4. Rangkuman Hasil Uji Signifikansi Regresi dan Uji Linearitas

\begin{tabular}{|c|c|c|c|c|c|c|c|c|}
\hline \multirow{3}{*}{ Dk } & \multirow{3}{*}{ Persamaan } & \multicolumn{3}{|c|}{ Uji Regresi } & \multicolumn{3}{|c|}{ Uji Linearitas } & \multirow{3}{*}{ Kesimpulan } \\
\hline & & \multirow[t]{2}{*}{$\mathbf{F}_{\text {hitung }}$} & \multicolumn{2}{|c|}{$\mathbf{F}_{\text {tabel }}$} & \multirow[t]{2}{*}{$\mathbf{F}_{\text {hitung }}$} & \multicolumn{2}{|c|}{$\mathbf{F}_{\text {tabel }}$} & \\
\hline & & & 0,01 & 0,05 & & 0,01 & 0,05 & \\
\hline $\begin{array}{c}\mathrm{X} 2 \\
\text { atas } \\
\mathrm{X} 1\end{array}$ & $\begin{array}{c}\mathrm{X}_{2}=51,784+ \\
0,222 \mathrm{X}_{1}\end{array}$ & $14.51^{* *}$ & 3,98 & 7,02 & $1.09^{\mathrm{NS}}$ & 1,79 & 2,27 & $\begin{array}{c}\text { Signifikan/ } \\
\text { Regresi linear }\end{array}$ \\
\hline $\begin{array}{c}\text { X3 } \\
\text { atas } \\
\text { X1 }\end{array}$ & $\begin{array}{c}\mathrm{X}_{3}=35,001+ \\
0,449 \mathrm{X}_{1}\end{array}$ & $36.26 * *$ & 3,98 & 7,02 & $0.91^{\mathrm{NS}}$ & 1,79 & 2,27 & $\begin{array}{c}\text { Signifikan/ } \\
\text { Regresi linear }\end{array}$ \\
\hline $\begin{array}{c}\mathrm{X} 4 \\
\text { atas } \\
\mathrm{X} 1\end{array}$ & $\begin{array}{c}\mathrm{X}_{4}=38,240+ \\
0,512 \mathrm{X}_{1}\end{array}$ & $37.42 * *$ & 3,98 & 7,02 & $0.76^{\mathrm{NS}}$ & 1,79 & 2,27 & $\begin{array}{c}\text { Signifikan/ } \\
\text { Regresi linear }\end{array}$ \\
\hline $\begin{array}{c}\mathrm{X} 4 \\
\text { atas } \\
\mathrm{X} 2\end{array}$ & $\begin{array}{c}\mathrm{X}_{4}=21,254+ \\
0,661 \mathrm{X}_{2}\end{array}$ & $13,44^{*}$ & 3,98 & 7,02 & $1,62^{\mathrm{NS}}$ & 1,96 & 2,56 & $\begin{array}{c}\text { Signifikan/ } \\
\text { Regresi linear }\end{array}$ \\
\hline $\begin{array}{c}\mathrm{X} 4 \\
\text { atas } \\
\mathrm{X} 3\end{array}$ & $\begin{array}{c}\mathrm{X} 4=23,824+ \\
0,687 \mathrm{X} 3\end{array}$ & $39,90 * *$ & 3,98 & 7,02 & $1,36 \mathrm{NS}$ & 1,8 & 2,3 & $\begin{array}{l}\text { Signifikan/ } \\
\text { Regresi linear }\end{array}$ \\
\hline
\end{tabular}


Tabel 4. Rangkuman Hasil Uji Signifikansi Regresi dan Uji Linearitas (lanjutan)

\begin{tabular}{|c|c|c|c|c|c|c|c|c|}
\hline \multirow{3}{*}{ Dk } & \multirow{3}{*}{ Persamaan } & \multicolumn{3}{|c|}{ Uji Regresi } & \multicolumn{3}{|c|}{ Uji Linearitas } & \multirow{3}{*}{ Kesimpulan } \\
\hline & & \multirow[t]{2}{*}{$\mathbf{F}_{\text {hitung }}$} & \multicolumn{2}{|c|}{$\mathbf{F}_{\text {tabel }}$} & \multirow[t]{2}{*}{$\mathbf{F}_{\text {hitung }}$} & \multicolumn{2}{|c|}{$\mathbf{F}_{\text {tabel }}$} & \\
\hline & & & $\mathbf{0 , 0 1}$ & 0,05 & & 0,01 & 0,05 & \\
\hline $\begin{array}{c}\mathrm{X} 5 \\
\text { atas } \\
\mathrm{X} 2\end{array}$ & $\begin{array}{c}X_{5}=46,076+ \\
0,214 X_{2}\end{array}$ & $5,06^{*}$ & 3,98 & 7,02 & $1,18^{\mathrm{NS}}$ & 1,96 & 2,58 & $\begin{array}{l}\text { Signifikan/ } \\
\text { Regresi linear }\end{array}$ \\
\hline $\begin{array}{c}\text { X5 } \\
\text { atas } \\
\text { X3 }\end{array}$ & $\begin{array}{c}X_{5}=47,057+ \\
0,219 X_{3}\end{array}$ & $12.14^{* *}$ & 3,98 & 7,02 & $0.59^{\mathrm{NS}}$ & 1,83 & 2,34 & $\begin{array}{l}\text { Signifikan/ } \\
\text { Regresi linear }\end{array}$ \\
\hline $\begin{array}{c}\mathrm{X} 5 \\
\text { atas } \\
\mathrm{X} 4\end{array}$ & $\begin{array}{c}X_{5}=38,896+ \\
0,328 X_{4}\end{array}$ & $51,77 * *$ & 3,98 & 7,02 & $1,44^{\mathrm{NS}}$ & 1,80 & 2,30 & $\begin{array}{l}\text { Signifikan/ } \\
\text { Regresi linear }\end{array}$ \\
\hline
\end{tabular}

Sumber: analisis penulis, 2009

Keterangan: $\mathrm{Dk}=$ derajat kebebasan; $*=$ signifikan pada taraf $\alpha=0,05$;

$* *$ sangat signifikan (pada taraf $\alpha=0,01$ dan $\alpha=0,05$ );

NS $=$ non signifikan (regresi linear).

\section{Pengujian Model}

Berdasarkan model kausal yang dibentuk secara teoretis akan diperoleh diagram analisis jalur dan dihitung nilai koefisien setiap jalurnya. Nilai yang perlu diketahui untuk perhitungan selanjutnya adalah nilai korelasi sederhana yang disajikan dalam bentuk matriks koefisien korelasi pada Tabel 5.

Tabel 5. Matriks Koefisien Korelasi Sederhana

\begin{tabular}{|c|c|c|c|c|c|}
\hline Variabel & $\mathbf{X 1}$ & $\mathbf{X 2}$ & $\mathbf{X 3}$ & $\mathbf{X 4}$ & $\mathbf{X 5}$ \\
\hline $\mathbf{X 1}$ & 1 & $0,419^{* *}$ & $0,590^{* *}$ & $0,596^{* *}$ & $0,456^{* *}$ \\
\hline $\mathbf{X} 2$ & $0,419^{* *}$ & 1 & $0,610^{* *}$ & $0,406^{* *}$ & $0,263^{*}$ \\
\hline $\mathbf{X 3}$ & $0,590^{* *}$ & $0,610^{* *}$ & 1 & $0,608^{* *}$ & $0,389^{* *}$ \\
\hline $\mathbf{X} 4$ & $0,596^{* *}$ & $0,406^{* *}$ & $0,608^{* *}$ & 1 & $0,657^{* *}$ \\
\hline $\mathbf{X 5}$ & $0,456^{* *}$ & $0,263^{*}$ & $0,389^{* *}$ & $0,657^{* *}$ & 1 \\
\hline
\end{tabular}

Sumber: analisis penulis, 2009

Keterangan:

X1=Kepemimpinan; X2=Kompetisi; X3=Ganjaran; X4=Motivasi kerja;

X5 = Efektivitas Organisasi $; *=$ Signifikan pada $\alpha=0,05 ; * *=$ sangat signifikan (pada $\alpha=0,01$ dan $\alpha=0,05$ ).

Untuk pengaruh kausal dari variabel-variabel yang diteliti, maka model teoretis yang coba dianalisis berdasarkan pemahaman konsep teoretis dan realitas di lapangan dapat dilihat pada Gambar 2. 


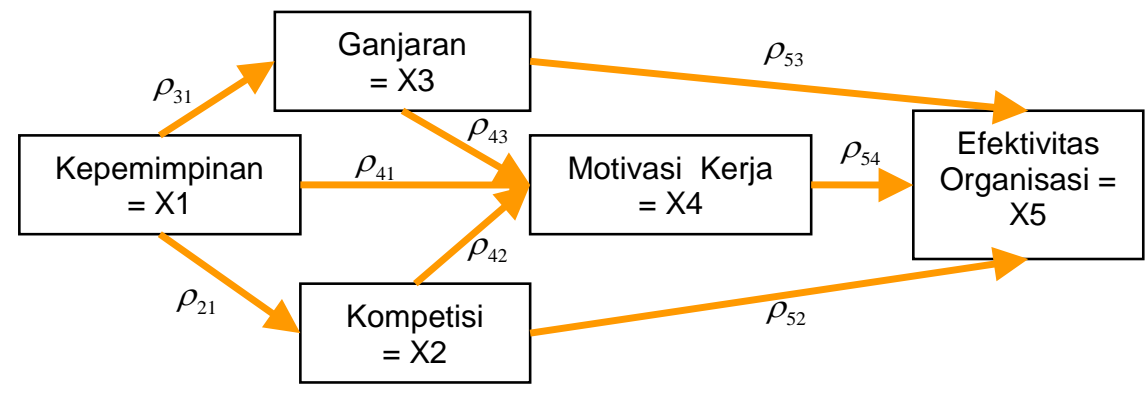

Gambar 2. Model Hubungan Struktural Antarvariabel

Dari diagram jalur ini diperoleh delapan buah koefisien jalur, yaitu $\rho_{21}, \rho_{31}, \rho_{41}, \rho_{42}, \rho_{43}$, $\rho_{52}, \quad \rho_{53}, \quad \rho_{54}$. Selanjutnya nilai koefisien untuk setiap jalur dihitung menggunakan program Lisrel dan diuji keberartiannya dengan menggunakan statistik uji t. Bila jalur yang diuji menunjukkan nilai koefisien jalur tidak berarti (tidak signifikan), maka jalur tersebut akan dihilangkan dan model hubungan struktural antarvariabel dimodifikasi serta nilai koefisien jalurnya dihitung kembali.

\section{Pengujian Hipotesis}

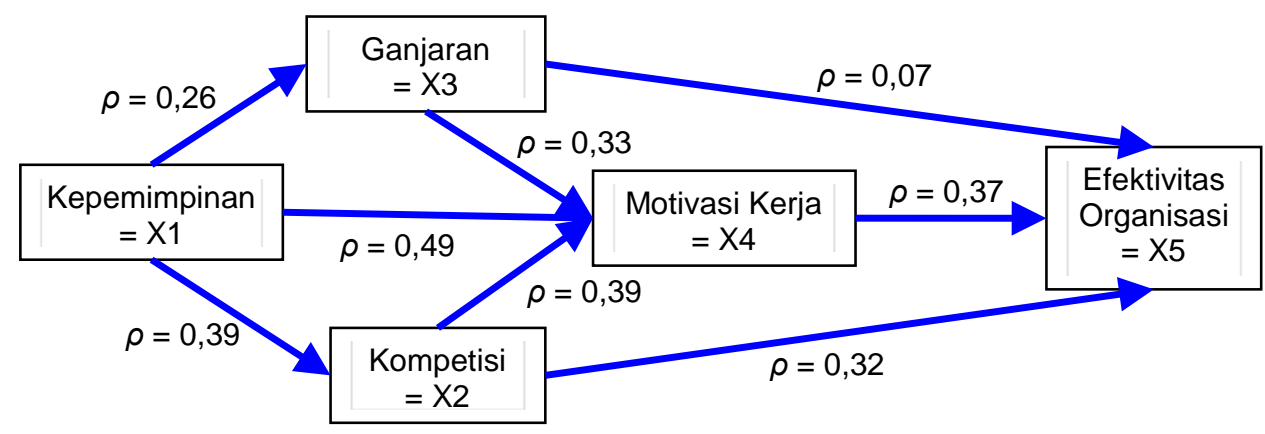

Tabel 6. Hasil Uji Signifikansi Jalur Kausal Penelitian

\begin{tabular}{|c|c|c|c|c|}
\hline No & Hipotesis & Uji Statistik & Keputusan & Kesimpulan \\
\hline 1. & $\begin{array}{l}\text { Motivasi kerja (X4) berpengaruh } \\
\text { langsung terhadap efektivitas } \\
\text { organisasi (X5) }\end{array}$ & $\begin{array}{l}\mathrm{H}_{0}: \rho_{54}=0 \\
\mathrm{H}_{\mathrm{i}}: \rho_{54}>0\end{array}$ & $\mathrm{H}_{0}$ ditolak & $\begin{array}{l}\text { Berpengaruh } \\
\text { langsung }\end{array}$ \\
\hline 2. & $\begin{array}{l}\text { Kompetisi (X2) berpengaruh langsung } \\
\text { terhadap efektivitas organisasi (X5) }\end{array}$ & $\begin{array}{l}\mathrm{H}_{0}: \rho_{52}=0 \\
\mathrm{H}_{\mathrm{i}}: \rho_{52}>0\end{array}$ & $\mathrm{H}_{0}$ ditolak & $\begin{array}{c}\text { Berpengaruh } \\
\text { langsung }\end{array}$ \\
\hline 3. & $\begin{array}{l}\text { Ganjaran (X3) berpengaruh langsung } \\
\text { terhadap efektivitas organisasi (X5) }\end{array}$ & $\begin{array}{l}\mathrm{H}_{0}: \rho_{53}=0 \\
\mathrm{H}_{\mathrm{i}}: \rho_{53}>0\end{array}$ & $\mathrm{H}_{0}$ ditolak & $\begin{array}{c}\text { Berpengaruh } \\
\text { langsung }\end{array}$ \\
\hline 4. & $\begin{array}{l}\text { Kepemimpinan (X1) berpengaruh } \\
\text { langsung terhadap ganjaran (X3) }\end{array}$ & $\begin{array}{l}\mathrm{H}_{0}: \rho_{31}=0 \\
\mathrm{H}_{\mathrm{i}}: \rho_{31}>0\end{array}$ & $\mathrm{H}_{0}$ ditolak & $\begin{array}{c}\text { Berpengaruh } \\
\text { langsung }\end{array}$ \\
\hline 5. & $\begin{array}{l}\text { Kepemimpinan (X1) berpengaruh } \\
\text { langsung terhadap kompetisi (X2) }\end{array}$ & $\begin{array}{l}\mathrm{H}_{0}: \rho_{21}=0 \\
\mathrm{H}_{\mathrm{i}}: \rho_{21}>0\end{array}$ & $\mathrm{H}_{0}$ ditolak & $\begin{array}{l}\text { Berpengaruh } \\
\text { langsung }\end{array}$ \\
\hline 6. & Kepemimpinan (X1) berpengaruh & $\mathrm{H}_{0}: \rho_{41}=0$ & $\mathrm{H}_{0}$ ditolak & Berpengaruh \\
\hline
\end{tabular}

\section{Volume XI}




\begin{tabular}{|c|l|l|l|c|}
\hline & langsung terhadap motivasi kerja (X4) & $\mathrm{H}_{\mathrm{i}}: \rho_{41}>0$ & & langsung \\
\hline \multirow{2}{*}{ 7. } & Ganjaran (X3) berpengaruh langsung & $\begin{array}{l}\mathrm{H}_{0}: \rho_{43}=0 \\
\mathrm{H}_{\mathrm{i}}: \rho_{43}>0\end{array}$ & \multirow{2}{*}{$\mathrm{H}_{0}$ ditolak } & $\begin{array}{c}\text { Berpengaruh } \\
\text { langsung }\end{array}$ \\
\hline \multirow{2}{*}{ 8. } & $\begin{array}{l}\text { Kompadap motivasi kerja (X4) } \\
\text { terhadap motivasi kerja (X4) }\end{array}$ & \multirow{2}{*}{$\mathrm{H}_{0}$ ditolak } & $\begin{array}{c}\text { Berpengaruh } \\
\text { langsung }\end{array}$ \\
\hline
\end{tabular}

Sumber: analisis penulis, 2009

\section{E. Perhitungan Pengaruh Langsung}

\begin{tabular}{|c|c|c|c|c|c|c|}
\hline \multirow[b]{2}{*}{ No } & \multirow[b]{2}{*}{ Pengaruh Langsung } & \multirow{2}{*}{$\begin{array}{l}\text { Koefisien nilai } \\
\text { Pengaruh }\end{array}$} & \multirow[b]{2}{*}{$\mathbf{t}_{\text {hitung }}$} & \multicolumn{2}{|c|}{$t_{\text {tabel }}$} & \multirow{2}{*}{$\begin{array}{l}\text { Signifikansi/ } \\
\text { keberartian }\end{array}$} \\
\hline & & & & $\mathbf{0 , 0 1}$ & 0,05 & \\
\hline 1. & $\begin{array}{l}\text { Pengaruh langsung } \\
\text { motivasi kerja (X4) } \\
\text { terhadap efektivitas } \\
\text { organisasi (X5) }\end{array}$ & 0,37 & 7,195 & 2,65 & 1,995 & $\begin{array}{l}\text { Signifikan/ } \\
\text { memiliki } \\
\text { keberartian }\end{array}$ \\
\hline 2. & $\begin{array}{l}\text { Pengaruh langsung } \\
\text { kompetisi (X2) terhadap } \\
\text { efektivitas organisasi (X5) }\end{array}$ & 0,32 & 2,249 & 2,65 & 1,995 & $\begin{array}{l}\text { Signifikan/ } \\
\text { memiliki } \\
\text { keberartian }\end{array}$ \\
\hline 3. & $\begin{array}{l}\text { Pengaruh langsung } \\
\text { ganjaran (X3) terhadap } \\
\text { efektivitas organisasi (X5) }\end{array}$ & 0,07 & 3,484 & 2,65 & 1,995 & $\begin{array}{l}\text { Signifikan/ } \\
\text { memiliki } \\
\text { keberartian }\end{array}$ \\
\hline 4. & $\begin{array}{l}\text { Pengaruh langsung } \\
\text { kepemimpinan (X1) } \\
\text { terhadap ganjaran (X3) }\end{array}$ & 0,26 & 6,021 & 2,65 & 1,995 & $\begin{array}{l}\text { Signifikan/ } \\
\text { memiliki } \\
\text { keberartian }\end{array}$ \\
\hline 5. & $\begin{array}{l}\text { Pengaruh langsung } \\
\text { kepemimpinan (X1) } \\
\text { terhadap kompetisi (X2) }\end{array}$ & 0,39 & 3,809 & 2,65 & 1,995 & $\begin{array}{l}\text { Signifikan/ } \\
\text { memiliki } \\
\text { keberartian }\end{array}$ \\
\hline 6. & $\begin{array}{l}\text { Pengaruh langsung } \\
\text { kepemimpinan (X1) } \\
\text { terhadap motivasi kerja } \\
\text { (X4) }\end{array}$ & 0,49 & 6,117 & 2,65 & 1,995 & $\begin{array}{l}\text { Signifikan/ } \\
\text { memiliki } \\
\text { keberartian }\end{array}$ \\
\hline 7. & $\begin{array}{l}\text { Pengaruh langsung } \\
\text { ganjaran (X3) terhadap } \\
\text { motivasi kerja (X4) }\end{array}$ & 0,33 & 6,317 & 2,65 & 1,995 & $\begin{array}{l}\text { Signifikan/ } \\
\text { memiliki } \\
\text { keberartian }\end{array}$ \\
\hline 8. & $\begin{array}{l}\text { Pengaruh langsung } \\
\text { kompetisi (X2) terhadap } \\
\text { motivasi kerja (X4) }\end{array}$ & 0,39 & 3,666 & 2,65 & 1,995 & $\begin{array}{l}\text { Signifikan/ } \\
\text { memiliki } \\
\text { keberartian }\end{array}$ \\
\hline
\end{tabular}

\section{F. Perhitungan Pengaruh Tidak Langsung dan Pengaruh Total}

Berdasarkan model analisis yang ditawarkan terdapat dua sub struktur persamaan yang dibentuk masing-masing yakni:

a. Sub struktur 1: persamaan struktural yang dibentuk oleh X1, X2 dan X3 secara bersama-sama terhadap X4. Persamaan struktur yang dimaksud:

$$
\begin{gathered}
\mathrm{X} 4=0,49 \mathrm{X} 1+0,39 \mathrm{X} 2+ \\
0,33 \mathrm{X} 3+0,591 ; \\
\mathrm{R}_{4.123}^{2}=0,651
\end{gathered}
$$

Persamaan struktur yang terbentuk dinyatakan signifikan dan dapat dijadikan sebagai alat prediksi untuk melihat gejala

\begin{tabular}{|l|c|c|c|}
\hline Volume XI & Nomor 01 & Maret 2010 & ISSN 1411-1829 \\
\hline
\end{tabular}


yang terjadi pada variabel $\times 4$ karena adanya perlakuan yang diberikan variabel X1, X2 dan X3.

b. Sub struktur 2: persamaan struktural yang dibentuk oleh X1, X2, X3 dan X4 secara bersama-sama terhadap $\times 5$. Persamaan struktur yang dimaksud:

$$
\begin{gathered}
\times 5=0,32 \times 2+0,07 \times 3+ \\
0,37 \times 4+0,803 ;
\end{gathered}
$$

$\mathrm{R}^{2}{ }_{5.234}=0,354$

Persamaan struktur yang terbentuk dinyatakan signifikan dan dapat dijadikan

\begin{tabular}{|c|c|c|c|c|c|c|c|}
\hline \multirow{3}{*}{$\begin{array}{c}\text { Pengaruh } \\
\text { Variabel }\end{array}$} & \multicolumn{6}{|c|}{ Pengaruh Kausal } & \multirow{3}{*}{ Total } \\
\hline & \multirow[b]{2}{*}{$\begin{array}{l}\text { Langsun } \\
\mathbf{g}\end{array}$} & \multicolumn{5}{|c|}{ Tidak Langsung } & \\
\hline & & $\begin{array}{c}\text { Melalui } \\
\text { X2 }\end{array}$ & $\begin{array}{c}\text { Melalui } \\
\text { X3 }\end{array}$ & $\begin{array}{c}\text { Melalui } \\
\text { X4 }\end{array}$ & $\begin{array}{l}\text { Melalui } \\
\text { X2 dan } \\
\times 4\end{array}$ & $\begin{array}{c}\text { Melalui } \\
\text { X3 dan } \\
\text { X4 }\end{array}$ & \\
\hline $\begin{array}{c}\mathrm{X} 1 \\
\text { terhadap } \\
\mathrm{X} 2\end{array}$ & 0,39 & & & & & & 0,39 \\
\hline $\begin{array}{c}\mathrm{X} 1 \\
\text { terhadap } \\
\text { X3 } \\
\end{array}$ & 0,26 & & & & & & 0,26 \\
\hline $\begin{array}{c}\mathrm{X} 1 \\
\text { terhadap } \\
\mathrm{X} 4\end{array}$ & 0,49 & 0,15 & 0,09 & & & & 0,73 \\
\hline $\begin{array}{c}\mathrm{X} 2 \\
\text { terhadap } \\
\text { X4 }\end{array}$ & 0,39 & & & & & & 0,39 \\
\hline
\end{tabular}

Tabel 8. Pengaruh Tidak Langsung Antarvariabel dan Pengaruh Total

\begin{tabular}{|c|c|c|c|c|c|c|c|}
\hline \multirow{3}{*}{$\begin{array}{c}\text { Pengaruh } \\
\text { Variabel }\end{array}$} & \multicolumn{6}{|c|}{ Pengaruh Kausal } & \multirow{3}{*}{ Total } \\
\hline & \multirow[b]{2}{*}{ Langsung } & \multicolumn{5}{|c|}{ Tidak Langsung } & \\
\hline & & $\begin{array}{l}\text { Melalui } \\
\quad \times 2\end{array}$ & $\begin{array}{c}\text { Melalui } \\
\quad \text { X3 }\end{array}$ & $\begin{array}{c}\text { Melalui } \\
\quad \times 4\end{array}$ & $\begin{array}{c}\text { Melalui } \\
\text { X2 dan } \\
\text { X4 }\end{array}$ & $\begin{array}{l}\text { Melalui X3 } \\
\text { dan X4 }\end{array}$ & \\
\hline $\begin{array}{c}\mathrm{X} 3 \\
\text { terhadap X4 }\end{array}$ & 0,33 & & & & & & 0,33 \\
\hline $\begin{array}{c}\mathrm{X} 1 \\
\text { terhadap X5 }\end{array}$ & & 0,12 & 0,02 & 0,18 & 0,06 & 0,03 & 0,41 \\
\hline $\begin{array}{c}\text { X2 } \\
\text { terhadap X5 }\end{array}$ & 0,32 & & & 0,14 & & & 0,46 \\
\hline $\begin{array}{c}\text { X3 } \\
\text { terhadap X5 }\end{array}$ & 0,07 & & & 0,12 & & & 0,19 \\
\hline $\begin{array}{c}\text { X4 } \\
\text { terhadap X5 }\end{array}$ & 0,37 & & & & & & 0,37 \\
\hline
\end{tabular}

Tabel 8. Pengaruh Tidak Langsung Antarvariabel dan Pengaruh Total (lanjutan)

Sumber: analisis penulis, 2009

Keterangan: $\mathrm{X} 1=$ kepemimpinan; $\mathrm{X} 2=$ kompetisi; $\mathrm{X} 3=$ ganjaran;

$\mathrm{X} 4=$ motivasi kerja; X5= efektivitas organisasi.

G. Tingkat Efektivitas di BPK RI

Berdasarkan hasil hasil kuesioner variabel efektivitas organisasi terhadap 70 responden

\begin{tabular}{|l|c|c|c|}
\hline Volume XI & Nomor 01 & Maret 2010 & ISSN 1411-1829 \\
\hline
\end{tabular}


dapat diketahui tingkat efektivitas organisasi BPK RI melalui perbandingan skor rata-rata responden per skor maksimal responden.

$\%$ tingkat efektivitas organisasi

$=\frac{\text { rata } 2 \_s k o r \_r e s p o n d e n}{\text { skor_maksimum_responden }} \times 100 \%$

$=\frac{59}{63} \times 100 \%=94 \%$

Berdasarkan hasil perhitungan tingkat efektivitas organisasi di BPK RI Jakarta sebesar $94 \%$ tergolong sangat tinggi.

\section{H. Pembahasan}

1. Pengaruh Variabel Kepemimpinan, Kompetisi, Ganjaran dan Motivasi Kerja terhadap Efektivitas Organisasi

Penelitian ini didasarkan pada teori Handy dalam Mullins mengenai faktor-faktor yang berpengaruh terhadap efektivitas organisasi. Dalam penelitian ini disusun model teoretik yang menggambarkan variasi pengaruh langsung dan tidak langsung variabel kepemimpinan, kompetisi, ganjaran dan motivasi kerja terhadap efektivitas organisasi. Model ini menjelaskan bahwa ada saling pengaruh antarvariabel eksogen dan endogen. Model ini juga dapat digunakan untuk mengetahui tingkat efektivitas organisasi di BPK RI Jakarta.

Berdasarkan model tersebut, dirumuskan 17 hipotesis. Hasil penelitian menunjukkan bahwa seluruh hipotesis diterima. Hal ini menerangkan bahwa efektivitas organisasi pada BPK RI Jakarta dipengaruhi oleh variabel kepemimpinan, kompetisi, ganjaran, dan motivasi kerja. Penelitian ini juga memperkuat teori Handy dalam Mullins mengenai efektivitas organisasi.

Motivasi kerja merupakan salah satu penunjang tercapainya efektivitas organisasi. Hasil penelitian menunjukkan bahwa efektivitas organisasi di BPK RI Jakarta sangat tinggi. Hal ini berarti terdapat motivasi kerja yang sangat tinggi pula di BPK RI Jakarta.

Motivasi kerja yang tinggi didukung oleh kepemimpinan yang baik di BPK RI Jakarta, karena pemimpin merupakan motivator bagi bawahannya. Pemimpin dapat membangkitkan semangat kerja bawahannya dengan berbagai strategi. Di BPK RI Jakarta, pemimpin sering mengadakan pendekatan kekeluargaan terhadap bawahannya. Hal ini membuat pemimpin lebih mengenal bawahannya. Dengan saling mengenal pemimpin dapat menerapkan langkah yang terbaik untuk meningkatkan motivasi kerja bawahannya.

Pemimpin merupakan figur teladan, pembimbing dan pemberi arahan bagi bawahannya. Sikap dan perilaku pemimpin sangat berpengaruh terhadap kerja bawahan. Kepemimpinan yang baik akan menghargai dan memperhatikan bawahannya. Hal itu terlihat di BPK RI dengan adanya pemberian ganjaran berupa piagam, tanda jasa, kesempatan melanjutkan pendidikan, dan sebagainya.

Ganjaran adalah bagian dari motivasi kerja. Semakin tinggi ganjaran yang diberikan seharusnya akan semakin tinggi pula motivasi kerja auditor. Di BPK RI Jakarta, ada sistem ganjaran yang diterapkan dalam rangka peningkatan motivasi kerja auditor.

Pemimpin merupakan pendorong adanya kompetisi di lingkungan kerja. Di BPK RI ada sistem penilaian kerja auditor oleh atasan langsung. Bagi yang berprestasi mendapat nilai khusus sehingga memacu kompetisi di antara auditor untuk meningkatkan kemampuan diri masing-masing agar dapat menjalankan tugas lebih baik.

Kompetisi mampu meningkatkan motivasi kerja. Kompetisi akan memacu semangat auditor untuk berusaha bekerja lebih baik dari pesaingnya. Di BPK RI Jakarta juga terjadi kompetisi yang sehat di antara para auditor. Terlihat dengan auditornya yang bersemangat untuk meningkatkan keahlian masing-masing dengan melanjutkan sekolah ke jenjang yang lebih tinggi dan mengikuti pelatihan-pelatihan. Adanya kompetisi dengan organisasi sejenis menjadikan BPK RI terus meningkatkan profesionalisme dalam pemeriksaan. Sehingga tingkat efektivitas organisasi BPK RI Jakarta semakin meningkat.

\section{Tingkat Efektivitas Organisasi BPK RI Jakarta \\ BPK yang sekarang merupakan lembaga} yang mandiri (independen), transparan, terpercaya dan profesional. Hasil penelitian menunjukkan bahwa tingkat efektivitas organisasi di BPK RI Jakarta sangat tinggi. Efektivitas 
organisasi yang sangat tinggi tercermin dalam capaian-capaian penting BPK RI pada masa sekarang berupa:

a. Hasil-hasil pemeriksaan yang menonjol;

b. Transparansi keuangan pusat dan daerah;

c. Pengembangan organisasi.

Selain itu, BPK RI merupakan lembaga yang paling terbuka dan transparan di Indonesia karena laporan keuangan BPK RI diperiksa oleh Kantor Akuntan Publik (KAP) yang ditunjuk oleh DPR. BPK RI juga diperiksa oleh lembaga sejenis (peer review) dari luar negeri.

\section{Keterbatasan Penelitian}

1. Penelitian ini hanya membahas empat variabel yang berpengaruh terhadap efektivitas organisasi, yaitu: kepemimpinan, kompetisi, ganjaran dan motivasi kerja;

2. Instrumen yang diajukan dalam penelitian ini sifatnya tertutup tanpa memberi kesempatan kepada responden untuk mengungkapkan alasan, kritik dan saran;

3. Instrumen yang digunakan berupa kuesioner berbentuk skala pengukuran tanpa dilengkapi dengan pedoman wawancara;

4. Sampel dalam penelitian ini terbatas pada responden auditor yang lama kerjanya minimal sepuluh tahun, pendidikan minimal S1 dan hanya golongan III dan IV;

5. Penelitian dilakukan hanya pada auditor BPK RI Jakarta (kantor pusat) bukan pada semua kantor BPK RI, sehingga belum mewakili BPK RI secara keseluruhan.

\section{KESIMPULAN, IMPLIKASI DAN SARAN}

\section{A. Kesimpulan}

Perubahan atau variasi yang muncul pada efektivitas organisasi dapat dipengaruhi oleh kompetisi, ganjaran, motivasi kerja dan kepemimpinan. Oleh karena itu, dalam rangka peningkatan efektivitas organisasi BPK RI, perlu diperhatikan variabel kompetisi, ganjaran dan motivasi kerja dalam rencana strategis (renstra) BPK RI.

\section{B. Implikasi}

\section{Implikasi Penelitian}

Penelitian ini memperkuat pengetahuan dan teori bahwa variabel efektivitas organisasi dipengaruhi oleh berbagai variasi dari variabel eksogen dan endogen. Dalam kaitan ini hasil penelitian yang diperoleh konsisten dengan model teoretik yang diusulkan.

Dengan merujuk pada model penelitian, maka dalam meningkatkan efektivitas organisasi, perlu dipertimbangkan untuk memperhatikan keempat variabel penelitian yaitu: kepemimpinan, kompetisi, ganjaran dan motivasi kerja.

\section{Implikasi Teoretis}

Upaya peningkatan efektivitas organisasi secara teoretis dapat dilakukan dengan melihat faktor-faktor yang bisa mempengaruhi suatu efektivitas organisasi. SDM merupakan salah satu faktor yang terbukti mampu mempengaruhi keefektifan suatu organisasi. Untuk itu perlu dipelajari bagaimana cara terbaik untuk mendapatkan calon-calon pemimpin masa depan, pemberian ganjaran yang memadai agar dapat memotivasi auditor yang ada agar bekerja lebih giat dan baik serta melakukan kompetisi yang sehat di BPK RI. Hal ini sangat diperlukan dan patut dijadikan sebagai bahan pertimbangan.

\section{Implikasi Kebijakan}

Adapun implikasi kebijakan dapat diuraikan melalui upaya peningkatan efektivitas organisasi melalui para auditor dengan memperhatikan variabel kepemimpinan, kompetisi, ganjaran dan motivasi kerja sebagai berikut:

a. Upaya Peningkatan Kepemimpinan yang Baik

1. Seleksi tes masuk BPK RI yang mampu melihat potensi calon-calon auditor yang memiliki kemampuan sebagai pemimpin di masa depan;

2. Pembinaan dan dukungan yang konkret untuk pemimpin di masa depan, salah satunya melalui pendidikan lanjutan di luar negeri untuk memperluas wawasan dari pemimpin masa depan BPK;

3. Suksesi yang ketat untuk menduduki suatu jabatan struktural yang didasarkan pada kinerjanya;

4. Pelatihan kepemimpinan

b. Upaya Peningkatan Kompetisi Sehat

\begin{tabular}{|l|l|l|l|}
\hline Volume XI & Nomor 01 & Maret 2010 & ISSN 1411-1829 \\
\hline
\end{tabular}


1. Memperluas kantor perwakilan BPK RI di daerah;

2. Meningkatkan jumlah auditor;

3. Menambah kapasitas jaringan telekomunikasi dan komputer sehingga dapat menjangkau seluruh obyek pemeriksaan di seluruh tanah air;

4. Mengadakan pelatihan untuk auditor secara rutin dan berjenjang di dalam dan luar negeri;

5. Modernisasi peralatan kerja dan fasilitas pendukung yang memadai;

6. Auditor harus memiliki sertifikasi baik lokal maupun internasional;

7. Sebagai auditor yang profesional, audit harus dilakukan sesuai standar pemeriksaan,

8. Kemampuan yang wajib dikuasai auditor antara lain melaksanakan audit ketaatan, memiliki pengetahuan mengenai berbagai peraturan, dan juga memiliki kemampuan manajemen publik, manajemen keuangan, manajemen pelayanan publik, serta kebijakan publik dan lain-lain;

9. Peningkatan kemampuan auditor berbasis kompetensi.

\section{c. Upaya Peningkatan Ganjaran yang Sesuai}

Peningkatan ganjaran dapat dilakukan dengan cara menciptakan hubungan yang selaras dengan sesama rekan kerja serta antara atasan dan bawahan antara lain dengan perlakuan yang adil, perhatian yang besar dan kompensasi yang sesuai.

Auditor yang berjasa diberikan penghargaan berupa tanda jasa (baik dari BPK atau pemerintah), serta promosi jabatan.

\section{d. Upaya Peningkatan Motivasi Kerja}

1. Mewujudkan suasana kerja yang kondusif, transparan dan akuntabel;

2. Kelengkapan fasilitas penunjang pemeriksaan yang modern;

3. Perluasan kantor perwakilan BPK RI;

4. Perbaikan sistem remunerasi auditor.

\section{Implikasi Praktis}

Untuk praktisnya perlu adanya seleksi yang ketat bagi calon auditor. Perlu peningkatan keterampilan dan pengetahuan auditor secara berkelanjutan agar mampu bekerja lebih baik. Dibarengi dengan ganjaran yang sesuai diharapkan auditor mampu meningkatkan motivasi kerjanya. Sehingga auditor mampu bersaing secara sehat baik dengan rekan kerja maupun dengan auditor lain dari lembaga sejenis.

\section{Saran}

\section{Bagi Auditor}

Auditor harus mampu mengembangkan diri melalui pelatihan audit baik tingkat lokal maupun internasional, serta peningkatan kemampuan berbasis kompetensi melalui pendidikan formal dan nonformal agar tercipta efektivitas organisasi yang tinggi.

\section{Bagi Pemimpin (pejabat struktural dari strata IV sampai dengan I)}

Pemimpin di BPK selayaknya mampu mempengaruhi orang untuk mengikuti suatu tindakan dengan menggunakan persuasi atau contoh, sebagai pemimpin harus menjalin hubungan dan kemitraan dengan orang lain, pemimpin harus mampu mengilhami, mempengaruhi, dan memotivasi orang lain dan menjadi ujung tombak dalam menggerakkan perubahan yang bermanfaat. Pemimpin diharapkan mampu mempertahankan BPK RI sebagai organisasi yang memiliki tingkat efektivitas yang sangat tinggi.

\section{Bagi BPK RI}

BPK RI senantiasa melaksanakan rencana kerja strategis BPK RI (renstra) 2006-2010 juga pada masa kepemimpinan badan yang baru (2009-2014) secara menyeluruh, sehingga siap menghadapi perubahan global dalam mempertahankan efektivitas organisasi yang sangat tinggi.

Pembenahan tidak hanya terfokus pada penambahan auditor namun dilakukan secara fundamental, berkesinambungan dan terintegrasi dalam bentuk pembenahan budaya, etika kerja, sistem kompensasi dan metode kerja, sehingga secara langsung dapat menciptakan akselerasi perwujudan akuntabilitas dan transparansi pertanggungjawaban keuangan negara sebagaimana tercantum secara jelas dalam renstra BPK RI 2006-2010 serta tercermin dalam visi dan misi BPK RI.

\section{Daftar Pustaka}

\begin{tabular}{|l|l|l|l|}
\hline Volume XI & Nomor 01 & Maret 2010 & ISSN 1411-1829 \\
\hline
\end{tabular}


Aguayo, Rafael. DR. Deming The American Who Taught the Japanese About Quality. New York: Simon \& Schuster, 1990.

Atkinson, John W. dan Birch, David. Introduction to Motivation. New York: Litton Educational Publishing, 1978.

Armstrong, Michael. Employee Reward. London: Institute of Personnel and Development, 1996.

Badan Pemeriksa Keuangan Republik Indonesia. BPK RI Menunaikan Amanat Konstitusi. Jakarta: BPK RI, 2009.

Rencana Strategis 2006-2010. Jakarta: BPK RI, 2006.

BPK RI dalam Angka 2005. Jakarta: BPK RI, 2006.

Bainbridge, Joseph R. Motivation Through Competition?, 1999. (http://www.almc.army.mil/alog/issues/Sep Oct99/MS418.htm).

Buckingham, Marcus. The One Thing You Need to Know. New York: Free Press, 2005.

Daft, Richard L. The Leadership Experience. Canada: South Western, 2005.

Gouillart, Francis J. dan Keelly, James N. Transforming the Organization. New York: McGraw-Hill, 1995.

Gibson, James L. et al. Organizations Behavior Structure Processes. Philippines: McGrawHill International Edition, 2006.

Luthans, Fred. Organizational Behavior. Singapore: McGraw-Hill, 1995.

Mullins, Laurie J. Management and Organisational Behaviour. Spain: MateuCromo, Artes Graficas, 2005.

Nelson, Bob. 1001 Cara untuk Memberikan Imbalan Kepada Karyawan terjemahan Arvin Saputra. Jakarta: Karisma publishing group, 2007.

Porter, Michael E. On Competition. Boston: Harvard business review book, 2002.

Keunggulan Bersaing terjemahan. Jakarta: Binarupa Aksara, 1994.
Robbins, Stephen P. dan Barnwell, Neil. Organizational Theory. New Jersey: Prentice-Hall International, 1990.

Sugiyono. Statistika untuk Penelitian. Bandung: Alfabeta, 2007.

Winardi, J. Manajemen Perubahan. Jakarta: Prenada Media Group, 2005.

Yukl, Gary A. Leadership in Organizations. New Jersey: Prentice-Hall, 1989. 